\title{
FAKTOR-FAKTOR YANG MEMPENGARUHI NIAT BERWIRAUSAHA PADA MAHASISWA S2 DI UNIVERSITAS DI JAKARTA YANG MENDAPATKAN MATA KULIAH KEWIRAUSAHAAN
}

\author{
Christopher Arnold \\ Program Studi Magister Manajemen Universitas Tarumanagara \\ christopherarnold59@yahoo.com
}

\begin{abstract}
This study aims to determine the effect of attitudinal factor, bahavioral factor, and educational support on entrepreneur intention. Methods of data collection using questionnaires. The respondents of this research are postgraduate students of Universitas Tarumanagara, Universitas Atmajaya, Universitas Prasetiya Mulya, and Universitas BinaNusantara. The method of data analysis using multiple regression. The results of the study conclude that attitudinal factor, bahavioral factor, and educational factor have a positive effect on entrepreneur intention either partially or simultaneously.
\end{abstract}

Keyword: Attitudinal factor, Behavioral factor, Educational support, entrepreneur intention.

\section{PENDAHULUAN}

Seiring Perkembangan kewirausahaan pada beberapa tahun terakhir sudah menjadi isu dibeberapa lembaga ekonomi mulai dari tingkat daerah, nasional hingga international. Hal ini diyakini bahwa kewirausahaan merupakan kunci untuk sejumlah hasil sosial yang diharapakan seperti pertumbuhan ekonomi, dan tingkat pengangguran yang lebih rendah (Baumol et al, 2011). Penumbuhan minat kewirausahaan menjadi salah satu faktor penting dalam pembangunan ekonomi mengingat kondisi kontras antara demand dan supply tenaga kerja. Berdasarkan Badan Pusat Statistik menunjukkan jumlah penduduk Indonesia sebesar 261 juta jiwa (2017), yang diikuti dengan tingkat pengangguran sebesar 5.5\% (2017). Tingginya tingkat pengangguran di Indonesia dikarenakan tingginya tingkat tenaga kerja dan relatif rendah permintaannya. Sementara itu, jumlah penyedia lapangan pekerjaan (entrepreneur) di Indonesia masih sedikit.

Schumpeter (1934), pertumbuhan ekonomi menyatakan entrepreneur memiliki peranan penting dalam pembangunan ekonomi dengan menciptakan inovasi, lapangan pekerjaan, dan kesejahteraan. Faktanya, pertumbuhan wirausaha di Indonesia masih belum mencapai angka ideal yaitu 2\% dari jumlah penduduk, saat ini Indonesia baru memiliki 1.6\% pelaku wirausaha dari seluruh populasi jiwa penduduk Indonesia (Afifudin, 2017). Keinginan penduduk Indonesia untuk berwirausaha yang masih rendah yang di pengaruhi oleh beberapa faktor. Salah satu upaya yang dapat mejadi alternatif dari permasalahan adalah menumbuhkan jiwa kewirausahaan mahasiswa perguruan tinggi Menurut Kusmintarti (2014), pemerintah Indonesia sedang berusaha untuk meningkatkan jumlah entrepreneur dengan mengubah cara pandang para mahasiswa yang bermula hanya ingin menjadi job seeker menjadi job creator. Salah satu upaya yang telah dilakukan oleh pemerintah Indonesia atas solusi dari permasalahan dihadapi adalah memberikan studi program entrepreneur, tujuannya adalah untuk memfasilitasi para mahasiswa yang memiliki ketertarikan untuk berwirausaha dan memulai suatu usaha (startup phase) yang diminiati berdasarkan pengetahuan bermakna . 
Berdasarkan Walipah dan Naim (2016), menyatakan terdapat beberapa faktor yang mempengaruhi minat mahasiswa untuk berwirausaha yaitu faktor internal dan faktor eksternal. Berdasarkan Bird (1993), Krueger dan Carsrud (1993), Shapero dan Sokol (1982), faktor Internal yang mempengaruhi minat berwirausaha adalah faktor sikap (Attitudinal factor) dan faktor perilaku (Behavioral factor) yang berasal dari dalam diri individu dan faktor eksternal adalah faktor yang berasal dari luar individu yaitu dukungan pendidikan (educational support). Attitudinal factor terdiri dari tiga dimensi yaitu Personality Traits, Locus of control dan Curiosity. Menurut Robbins dan Judge (2008), Personality traits adalah suatu karakteristik yang bertujuan untuk mendeskripsikan perilaku seorang individu dalam mengahadapi berbagai situasi. Kemudian, Locus of control adalah atribut yang mengindikasikan rasa kontrol individu terhadap hasil, penghargaan, kesuksesan dan kegagalan (Strauser et al, 2012). Curiosity adalah motivator utama perilaku dalam domain seperti pendidikan dan pekerjaan (Gottlieb et al. 2013).

Kemudian, Behavioral factor memiliki dua dimensi yaitu Creativity dan Risk taking. Disadari bahwa, tingkat kreatifitas didefinisikan sebagai kemampuan untuk mengembakan ide - ide baru dan cara - cara baru dalam pemecahan masalah dan menemukan peluang (Baldacchino, 2009). Menurut Hadiyati (2011), seorang wirausaha haruslah memiliki kreatifitas yang baik agar dapat menghasilkan suatu inovasi baru. Kemudian Risk Taking adalah kecenderungan individu untuk pengambilan risiko dan menghindari risiko saat dihadapkan pada suatu kondisi, akan tetapi entrepreneur identik dengan seorang individu yang melakukan pengambilan risiko (Kadir, 2012). Terakhir, educational support adalah faktor yang berkaitan dengan dukungan bagi mahasiswa untuk mencapai pengetahuan tentang kewirausahaan secara efisien (Alwisol, 2009). Namun, realita yang dihadapi tidak sesuai yang diharapkan, masih banyak mahasiswa yang terdidik dan professional masih lemah dalam mengembangkan ilmu kewirausahaannya bahkan tidak berani dalam mengambil risiko.

Dengan demikian, universitas di Jakarta merupakan beberapa universitas yang membantu pendidikan dan kemajuan perkembangan generasi muda, serta menciptakan pendidikan yang berkualitas sesuai dengan kebutuhan industri agar menciptakan lulusan yang berkualitas. Melihat realita yang ada maka peneliti ingin melakukan penelitian tentang pengaruh Attitudinal factor, Behavioral factor dan Educational support terhadap Entrepreneurial Intentions pada mahasiswa S2 yang mendapatkan kelas entreprenuer di beberapa universitas di Jakarta. Mahasiswa S2 sangat ideal untuk dijadikan responden dalam penelitian ini karena diasumsikan pada umumnya mahasiswa tersebut memiliki tingkat pengetahuan yang cenderung lebih tinggi terhadap entrepreneurship dan sudah hampir selesai menempuh masa kuliahnya dan akan mulai memasuki dunia pekerjaan sehingga lebih relevan untuk digunakan sebagai responden dalam penelitian ini.

\section{LANDASAN TEORI}

\section{Entrepreneur Intention}

Berdasarkan Karabulut (2016), entrepreneurial intention menunjukkan niat seseorang untuk memilih menjadi entrepreneur untuk karirnya, seorang yang memiliki entrepreneurial intention berencana untuk mengambil risiko yang telah diperhitungkan, mengumpulkan sumber daya yang dibutuhkan dan membangun usahanya sendiri. Berdasarkan Linan dan Chen (2006), niat berwirausaha merupakan langkah awal dari suatu proses pendirian sebuah usaha yang bersifat jangka panjang. Perhatian terhadap niat kewirausahaan sudah semakin meningkat untuk diteliti yang diyakini bahwa suatu niat berkaitan dengan perilaku. Menurut Ajzen (1975) dalam Cameron, Ginsburg, dan Westhoff (2012), Dalam teori planned behavior diyakini bahwa faktor seperti sikap (individual's attitude), dan norma subyektif (subjective norms) yang akan membentuk niat seseorang secara langsung yang mempengaruhi perilaku. 
Cameron, Ginsburg dan Westhoff (2012), terdapat faktor internal yang berasal dari dalam diri wirausaha yang bersifat personal, sikap, kemauan dan kemampuan individu untuk berwirausaha, disisi lain faktor eksternal berasal dari likungan sekitar seperti keluarga, pendidikan, sosial dan ekonomi. Akan tetapi, pada penelitian menurut Ferreira et al. (2012), terdapat beberapa faktor yang mempengaruhi niat seorang individu untuk berwirausaha yaitu physiological approach dan Behavioral approach. Pada physiological approach terdiri dari locus control, propensity to risk, self-confidence, need for achievement, tolerance of ambiguity dan innovativeness. Sedangkan pada behavioral approach terdiri dari personal attitude, subjective norm, dan perceived behavioral control.

Beberapa faktor yang mempengaruhi niat berwirausaha adalah faktor sikap (Attitudinal factor) dan faktor perilaku (Behavioral factor) yang berasal dari dalam diri individu dan faktor eksternal adalah faktor yang berasal dari luar individu yaitu dukungan pendidikan (educational support) Bird (1993), Krueger dan Carsrud (1993), Shapero dan Sokol (1992). Penelitian terdahulu juga didukung oleh Boyd dan Vozikis (1994), yang menyatakan bahwa niat berwirausaha (entrepreneur intention) juga telah didasarkan pada teori kognitif psikolog yang sebenarnya juga ingin menjelaskan dan memprediksi perilaku (behavior) individu.

Studi ini menemukan pendekatan baru untuk mendapatkan komprehensif gambaran untuk niat kewirausahaan. Kami memutuskan untuk berfokus pada tiga sumber faktor yang mempengaruhi niat berwirausaha baik faktor internal (attitudinal factor dan behavioral factor) dan faktor ekternal (education support) untuk memprediksi niat mahasiswa Universitas di Jakarta untuk menjadi seorang wiraswasta.

\section{Attitudinal Factor}

Definisi Attitudinal factor atau yang dikenal dengan faktor sikap, dijelaskan bahwa sikap merupakan kepercayaan dan perasaan yang dimiliki oleh seseorang mengenai ide dan situasi tertentu, atau mengenai orang lain (Kemala, 2017). Menurut Cruzet al. (2015), sikap adalah kecenderungan bereaksi secara efektif menanggapi risiko dalam bisnis. Kemudian, berdasarkan Oetomo dan Santoso (2016), Sikap merupakan kepercayaan positif dan negatif untuk menampilkan suatu perilaku tertentu, dimana seorang individu memiliki niat untuk menampilkan perilaku tertentu secara positif. Sikap ini terdiri dari dua aspek pokok yaitu menampilkan atau tidak menampilkan perilaku tertentu yang akan menghasilkan akibat tertentu. Semakin positif keyakinan individu akan berakibat pada suatu obyek sikap, maka akan semakin positif pula sikap individu terhadap obyek sikap, demikian sebaliknya.

Pernyataan ini juga didukung oleh Mc Clelland berdasarkan buku "The Achieving Society" menyatakan seorang wirausaha adalah seseorang yang memiliki keinginan untuk berprestasi jika dibandingkan dengan seseorang yang tidak berwirausaha, sikap merupakan salah satu faktor pendorong yang mempengaruhi minat berwirausaha untuk lebih unggul.

Faktor pertama yang menjadi independen variable yang akan digunakan dalam studi ini. Berdasarkan Gurbuz et al. (2008), telah ditemukan beberapa attitudinal factor yang berpengaruh pada niat berwirausahadalam Theory of Planned Behavior yang diadopsi dari Ajzen (1975). Attitudinal factor yang terdapat dalamTheory of Planned Behavior terdiri dari authority, economic challenge, self-realization, perceived confidence, security \& workload, avoid responsibility dan social career.

Beberapa studi sebelum telah menyoroti faktor sikap terhadap niat kewirausahaan, salah satu faktor yang mempengaruhi attitudinal factor adalah Personal Traits(Khuongdan An, 2016). Menurut Ciavarella et al. (2004), personality traits telah diyakini sebagai salah satu faktor untuk memprediksi niat berwirausaha, personality traits dijelaskan sebagai konstruksi keteraturan dalam perilaku seseorang. Terdapat lima dimensi kepribadian mendasar yaitu extroversion, neuroticism, agreeableness, conscientiousness dan openness to 
experience. Menurut Iregun dan Arikboga (2015), extroversion adalah seseorang yang positif, dan bersosialisasi dalam hubungan mereka, dan diklaim bahwa orang yang memiliki sifat extroversion lebih dominan untuk kegiatan yang bersifat positif, energetik, dan asertif. Kemudian, neuroticism adalah faktor yang menunjukan keseimbangan seseorang dalam mengendalikan emosi, emosi yang timbul dapat berupa emosi positif yaitu kemarahan, kesedihan dan kecemasan. Seorang entrepreneur yang memiliki nilai tinggi pada dimensi agreeables adalah seorang individu yang menyenangkan, dapat dipercaya dan lebih memilih untuk bekerja sama daripada persaingan. Menurut Burger (2006) didalam jurnal Iregun dan Arikboga (2015), conscientiousness merupakan kemampuan seseorang untuk mengkontrol dan disiplin suatu karya yang mereka ciptakan, biasanya individu ini memiliki hubungan erat dengan sikap perfeksionis. Openness adalah sebuah kemampuan individu dalam mengambil risiko, karena ini adalah salah satu sifat mendasar yang harus dimiliki oleh seorang enterprenuer.

Berdasarkan Remeikiene et al. (2013), personality traits adalah suatu sikap positif terhadap inisiatif untuk berwirausaha atau memulai usaha, dan diyakini faktor yang mempengaruhi personality traits terdiri dari self-efficicacy, risk taking, need for achievement, attitude towards entrepreneurship, behavioral control, locus control dan pro-activeness.

Menurut Karabulut (2016), Locus of control (LOC) adalah ukuran kepercayaan seorang individu dalam kemampuan mereka dalam mengendalikan lingkungan melalui tindakan mereka, LOC terbagi menjadi dua yaitu LOC internal dan LOC eksternal.LOC internal adalah suatu keadaan dimana seseorang mempercayai bahwa keputusannya dapat mengendalikan hidupnya sedangkan LOC eksternal adalah keadaan hidup seseorang terpengaruh oleh faktor eksternal seperti takdir, keberuntungan, dan orang lain diluar keputusannya. Seseorang yang memiliki $L O C$ diharapkan dapat menentukan jalur karir mereka, dengan memiliki usaha dan memulai bisnisnya sendiri. Berdasarkan beberapa studi yang telah dilakukan oleh (Brockhaus dan Horwitz, 1986; Hansemark, 1998; Mueller dan Thomas, 2000; Gürol dan Atsan, 2006) dalam penelitian Karabulut (2016), menyatakan bahwa $L O C$ internal mempengaruhi niat berwirausaha, dan seseorang yang memiliki LOC internal yang tinggi akan lebih sering mengabil risiko dalam membangun bisnisnya.

Menurut Reio \& Wiswell (2000), curiosity telah diidentifikasikan sebagai motivator utama perilaku (behaviour) di bidang pendidikan, dan pekerjaan. Studi yang telah dilakukan oleh Kashan \& Robert (2004) menemukan bahwa seorang individu sangat termotivasi untuk mempelajari lingkungan baru untuk mendapatkan informasi kognitif, persepsi dan informasi yang bermanfaat untuk memenuhi keingintahuannya. Berdasarkan uraian tersebut maka hipotesis penelitian:

H1: Attitudinal factor (Personality Traits,Locus of controldan Curiosity) bepengaruh terhadap niat untuk berwirausaha.

\section{Behavioral Factor}

Salah satu faktor yang mempengaruhi niat berwirausaha adalah faktor perilaku (behavior). Menurut Ferreira et al. (2012), behavioral factor adalah salah satu faktor terpenting dalam mempengaruhi niat berwirausaha. Terdapat beberapa definisi menurut para ahli terkait behavioral factor yaitu faktor yang mencerminkan persepsi sulit atau tidak dalam mengambil tindakan atau keputusan berdasarkan refleksi dari pengalaman dan antisipasi masa lalu dari rintangan (Utami, 2017). Hal ini diyakini bahwa behavioral control dapat dilihat dari seleksi individu terhadap kewiraswastaan daripada berkerja untuk orang lain, dan mempercayai kemampuan untuk mengelola bisnis yang dimilikinya.

Adapula pandangan berdasarkan Cruzet (2015), behavioral factor adalah suatu kondisi dimana orang percaya bahwa suatu tindakan sulit atau mudah untuk dilakukan, 
biasanya berbentuk Self-efficacy yang berhubungan dengan keyakinan diri seseorang untuk melakukan tindakan yang diharapkan. Behavioral factor didefinsikan sebagai penemuan, evaluasi dan eksploitasi sebuah kesempatan, dimana setiap jenis perilaku terdiri dari serangkaian tindakan yang dilakukan oleh seorang individu secara bersamaan dengan kondisi eksternal dan internal atau sering diketahui sebagai preferensi pribadi (Shirokova et al., 2015).

Disisi lain, Behavioral factor adalah salah satu konsep kewirausahaan yang sedang berkembang, ada kebutuhan dalam mengembangkan kemampuan dalam mengahadapi tantangan pada masa kini dan masa depan. Pada penelitian terdahulu Honig (2004), menyatakan bahwa behavioral factor yang mempengaruhi niat berwirausaha terdiri dari personal attitude, Subjective Norms, dan Perceived Behavioral control. Semakin tinggi behavioral control yang dimiliki, semakin kuat niat seseorang untuk menjadi seorang wiraswasta. Berdasarkan penelitian terdahulu, behavioral factor menekan kepada faktor psikologis dan non-psikologis yang bertujuan untuk menjelaskan alasan seseorang memulai sebuah bisnis. Sedangkan, menurut Shapero \& Sokol (1982), behavioral factor yang mempengaruhi niat berwirausaha terbagi menjadi creativity dan risk taking.

Berdasarkan Biraglia \& Kadile (2017), creativity merupakan salah satu faktor penting, yang sering dibicarakan dalam pembentukan niat kewirausahaan, yang berhubungan dengan perilaku (behavior) karena ini berhubungan dengan mengidentifikasikan kesempatan yang mengarah kepada proses pendirian perusahaan baru. Dengan kehadiran creativity akan menyebabkan seseorang untuk menjadi pengusaha, dan bila didukung dengan generasi aktif dalam pemecahan masalah. Dapat disimpulkan bahwa, creativity akan berpengaruh niat seseorang untuk berwirausaha. Menurut (Hunter, Bedellm \& Mumford, 2007), kreatifitas akan timbul pada saat berinteraksi antar individu dan lingkungan. Dengan memiliki kreatifitas ini dapat memfasilitasi harapan masyarakat yang ditarik dari kesuksesan pada masa lalu diberbagai bidang, dan yang terpenting adalah mengamati keberhasilan lainnya pada lingkungan yang sama. Menurut Nishantha (2009), Risk Taking adalah mengacu pada orientasi individu untuk mengambil keputusan dalam ketidakpastian. Diyakini oleh wei ni et al. (2012), pengusaha lebih memilih pengambilan risiko sedang, sedangkan pengusaha yang berpendidikan tinggi memiliki kecenderungan dan toleransi risiko yang lebih tinggi terhadap ketidakpastian. Berdasarkan Taramisi Sama - Ae (2009), risk taking adalah keadaan dimana melakukan pengambilan risiko secara signifikan dan secara positif mempengaruhi niat berwirausaha. Risk taking memiliki kecenderungan yang tidak signifikan terhadap niat berwirausaha terhadap latar belakang keluarga. Berdasarkan uraian tersebut maka hipotesis penelitian:

H2: Behavioral factor(Creativity dan Risk Taking)bepengaruh terhadap niat untuk berwirausaha.

\section{Educational Support}

Berdasarkan UU SISDIKNAS No.20, (2003), edukasi atau yang biasa disebut dengan pendidikan merupakan proses pembelajaran yang berarti melalui proses perkembangan dan perubahan kearah yang lebih baik pada seorang individu atau kelompok yang dari tidak tahu tentang nilai - nilai menjadi tahu. Akan tetapi, edukasi kewirausahaan didefinisikan sebagai ruang lingkup pelajaran yang memberikan siswa kompetensi kewiraswastaan, keterampilan dan pengetahuan dalam mengejar karir untuk berwirausaha (Wei Ni et al., 2012).

Edukasi kewirausahaan merupakan salah satu faktor terpenting, karena pendidikan memberikan perasaan mandiri dan percaya diri kepada individu, memberikan alternatif karir dan memperluas pengetahuan seorang individu dalam mengembangkan peluang bisnis baru (Dogan, 2015). Keong (2008) menjelaskan, pendidikan kewirausahaan adalah memberikan 
pengajaran kepada generasi muda untuk melihat peluang dan bertindak dalam semangat tanpa memperdulikan posisi, pekerjaan dan profesi seseorang. Menurutnya, banyak orang untuk menghindari masalah dan melupakan inovasi, tetapi tidak untuk seorang pengusaha. Seorang pengusaha akan selalu memberikan ide, pendekatan, metode terbaru dalam berwirausaha.

Dengan pendidikan kewirausahaan yang cukup, seorang individu dapat memperoleh keterampilan dan pengetahuan dalam mengembangkan bisnis baru. Akan tetapi, niat berwirausaha seseorang individu dapat berubah selama program pendidikan bukan pelajaran tentang kewirasusahaan itu sendiri melainkan tentang diri mereka dan kemampuannya (Sanchez, 2011).

Menurut Suharti \& Sirine (2002), Beberapa faktor eksternal yang cukup mendapat perhatian peneliti adalah peranan pendidikan kewirausahaan dan pengalaman kewirausahaan. Selain pendidikan dan pengalaman kewirausahaan, dukungan pihak akademik (academic support), social support dan dukungan lingkungan usaha (Gurbuz, 2008) yang diduga merupakan faktor eksternal yang berpengaruh terhadap niat kewirausahaan. Menurut Selvarajah \& Meyer (2011), pendidikan kewirausahaan mengacu pada lingkup kurikulum yang diberikan kepada mahasiswa dengan kompetensi, ketrampilan dan pengetahuan kewirausahaan.

Berdasarkan Shapero \& Sokol (1982), dukungan pendidikan terdiri dari syllabus dan pedagogy.Syllabus didefinisikan sebagai intruksi dan perintah untuk mengajar, ini adalah salah satu fitur penting untuk mengatur preferensi mengajar antara guru dan mahasiswa (Suter, 2001). Silabus adalah rencana pembelajaran pada suatu kelompok mata pelajaran/tema tertentu yang mencakup standar kompetensi, kompetensi dasar, materi pokok/pembelajaran, kegiatan pembelajaran, indikator, penilaian, alokasi waktu, dan sumber/bahan/alat belajar. Silabus merupakan penjabaran standar kompetensi dan kompetensi dasar ke dalam materi pokok/pembelajaran, kegiatan pembelajaran, dan indikator pencapaian kompetensi untuk penilaian.

Pedagogy diidentifikasikan sebagai strategi komunikatif yang ditinjau dari intervensi namun mendapatkan rincian lebih lanjut tentang feedback dan perhatian guru, kerja kelompok, dan penjelasan dalam kelas (Westbrook et al., 2013). Menurut Bernstein (2000), pedagogy adalah sebuah proses yang berkelanjutan dimana seorang individu memperoleh bentuk baru atau mengembangkan perilaku, pengetahuan, praktik dan kriteria yang ada didalam diri seseorang dan sebagai evaluator yang tepat. Pedagogy terdiri dari ideas, beliefs, attittudes, knowledge dan understanding tentang kurikulum. Berdasarkan UNESCO (2005), tujuan utama dari pedagody adalah untuk mengembangkan pembelajaran siswa yang meliputi kreatifitas, emosional dan sosial sebagai kualiatas indikator pembelajaran. Pendidikan kewirausahaan membutuhkan pengajaran pedagogi yang berbeda dimana pendidikan kewirausahaan terkait dengan pembelajaran yang berhubungan dengan pekerjaan, pengalaman belajar, action learning, dan pelatihan kewirausahaan (Westbrook et al., 2013).

Menurut Wang \& Wong (2004), Dukungan pendidikan melalui pendidikan professional merupakan cara yang efisien dalam mendapatkan pengetahuan yang diperlukan tentang kewirausahaan. Sistem pendidikan juga berperan penting dalam mengidentifikasikan niat untuk berwirausaha. Berdasarkan uraian tersebut maka hipotesis penelitian:

H3: Educational support (Syllabus dan Pedagogy) bepengaruh terhadap niat untukberwirausaha.

\section{METODE PENELITIAN}

Jenis penelitian ini adalah penelitian kuantitatif. Sumber data dalam penelitian ini adalah data primer yang merupakan hasil kuesioner dari mahasiswa S2 di Jakarta yaitu Universitas Tarumanagara, Universitas Atmajaya, Universitas Prasetiya Mulya, dan 
Universitas BinaNusantara. Metode pengumpulan data yang digunakan dalam penelitian ini adalah dengan menggunakan kuesioner. Metode analisis data menggunakan regresi ganda.

HASIL ANALISIS DATA

Tabel 1

Hasil Regresi

\begin{tabular}{|l|c|c|c|}
\hline \multicolumn{1}{|c|}{ Variabel } & $\mathrm{B}$ & $\mathrm{t}$ & Sig. \\
\hline Attitudinal Factor & 0,129 & 6,547 & 0,000 \\
\hline Behavioral Factor & 0,328 & 9,950 & 0,000 \\
\hline Educational Support & 0,461 & 13,430 & 0,000 \\
\hline $\mathrm{F}$ & \multicolumn{3}{|c|}{0,000} \\
\hline $\mathrm{R}^{2}$ & \multicolumn{3}{|c|}{0,959} \\
\hline
\end{tabular}

Berdasarkan hasil analisis yang disajikan pada Tabel 1, didapat nilai sig sebesar 0,000 untuk pengaruh attitudinal factor terhadap entrepreneur intention yang artinya sig < 0,05. Oleh karena itu terdapat pengaruh attitudinal factor terhadap entrepreneur intention. Berdasarkan hasil analisis yang disajikan pada Tabel 1, didapat nilai sig sebesar 0,000 untuk pengaruh behavioral factor terhadap entrepreneur intention yang artinya sig $<0,05$. Oleh karena itu terdapat pengaruh behavioral factor terhadap entrepreneur intention. Berdasarkan hasil analisis yang disajikan pada Tabel 1, didapat nilai sig sebesar 0,000 untuk pengaruh educational factor terhadap entrepreneur intention yang artinya sig $<0,05$. Oleh karena itu terdapat pengaruh educational factor terhadap entrepreneur intention

Berdasarkan Tabel 1 besarnya koefisien determinasi berdasarkan $\mathrm{R}$ square adalah 0,959 artinya sebesar 95,9\% variasi entrepreneur intention dapat dijelaskan oleh variabel attitudinal factor, behavioral factor, dan educational factor. Sisanya dijelaskan oleh variabel lain.

\section{KESIMPULAN}

Berdasarkan penelitian dan pembahasan yang telah dijelaskan pada analisis data maka dapat diambil beberapa kesimpulan sebagai berikut:

1. Terdapat pengaruh Attitudinal Factor (Personality Traits, Locus of Control, Curiosity)terhadap Entrepreneur Intention.

2. Terdapat pengaruh Behavioral Factor (Creativity, Risk Taking)terhadap Entrepreneur Intention.

3. Terdapat pengaruh Educational Support (Syllabus dan Pedagogy)terhadap Entrepreneur Intention. 


\section{DAFTAR PUSTAKA}

Adhitama, P.P. (2014). Faktor - faktor yang Mempengaruhi Minat Berwirausaha (Studi Kasus). Semarang : UNDIP.

Adi Sutanto. 2002. Kewiraswastaan. Malang : Ghalia Indonesia.

Afifudin. (2017, Januari 15). HIPM: Jumlah Pengusaha Baru $1.6 \%$ dari penduduk RI. Retrived from http://www.suara.com/bisnis/2017/01/15/160506/hipmijumlah-pengusaha-baru-16-persen-dari-jumlahpenduduk-ri

Alwisol. (2009). Psikologi Kepribadian edisi revisi. Malang : UMM Press.

Ajzen, I. \& Fishbein, M. (1975). Belief, Attitude, Intention, and Behavior: An Introduction to Theory and Research. Reading, MA: Addison-Wesley.

Ajzen, I. (1988). Attitudes, personality, and behavior. Milton Keynes: Open University Press.

Annabelle, M. (2012). Perbedaan Kewirawastaan dan Perusahaan Kecil. Jurnal ekonomika Universitas Almuslim Bireuen, Vol. III (5).

Arikboga, F.S. (2015). The effect of Leader Behavior on Job Satisfcation. Procedia - Science and Behavioral Science.

Aritonang, R. Lerbin, R. (1998). Penelitian Pemasaran. Jakarta: UPT Universitas Tarumanagara.

Perusahaan, Jurnal, Pengembangan Wiraswasta Vol.11 No. 2 Hal.142-152 Agustus2009.

Yurtkoru, E.S., Acar, P. \& Teraman, B.S. (2014).

Willngness to take risk and enterprenewrial intention of unviversity students: An emperical study comparing private and state universitites. ELSEVIER vol. 150 , pp. 834-840.

Zampetakis,L.A. \& Moustakis, V. (2006). Linking creativity with entrepreneurial intentions: $A$ structural approach Entrepreneurship management, DOI: 10.1007/s11365-006$0006-z$
Asmani, J.M.(2011). Buku Panduan Internalisasi Pendidikan Karakter. Jogjakarta: Diva Press.

Baldacchino, L. (2009). Entrepreneurial Creativity of Rural Entrepreneurs: A Gender Based Assessment. Intermational Journal of Novel Research in Humanity and Social Science Vol.2, Issue 4, p. 106-110.

Baum, J., Lemp, M.A., Baudouin, C., et al. (2007). The Definition and Classification Subcommittee of the Intemational Dry Eye Workshop 2007, 5 (2): 75-92

Baumol, W \& Blinder, A. (2011). Economic Principle Policy. Penerbit South Westem, Cengage Leaming.

Baumol, W. J. (1990). Entrepreneurship in Economic Theory. American Economic Association, 58(2), 64-71.

Begam, M. \& Tung, L.C. (2012). The Impact of Entrepreneurship Eclucation on Entrepreneurial Intention of Engineering Students. City University of Hongkong: Run Run Show Library

Bemstein, B.B. (2000). Pedagogy, Symbolic Control, and Indentity: Theory, Research, Critique. Roman \& Littlefield, p. 229.

Biraglia, A. \& Kadile, V. (2017). The Role of Entrepreneurial Passion and Creativity in Developing Entrepreneurial Intentions: Insight from American 
Homebrewers. Journel of ra" bainean management Vol. $55(1), 7.170-138$

Bird, B. (1963). Implementrog Eedogrenewial Ldeas: The care for tnicntien. Aendemy of Management Review. Vol $13,3,442-451$

Benas, W. A Jaroveh, M. ( 1011 ). Oender Differenee in Competitiveness, Rik Talernes, and ather Derroeslity Treitr. Do they contributs to the Oender Oxp in Entreprensurhip? Sehurgeter Diveasios Dapen, Sehumpetsr Sthosl of Buinen and Exonemien, Uhiverrity of Wuppertal, Oermany.

Bayd, N., \& Verikin, $Q$. (1994). The Iflower of Seif. Efflesey on the Develagment of Entrogrenturial

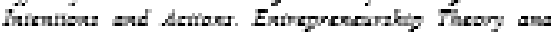
Draenec, of. $62-77$

Burger, I. M. (2006) Negaine of Derzanality hed Sseia' Druchology: S\& (2) 246-256

Cemersa, D. Giniturg, म., Wenthef, M, Mender, R. V. (2012). Ajren'a Teeary of Dlaned Behevior and Sosin? media Uas by College Studenta. Amerien Joumal of Dryehologital Reveareh Detrieved for bur:

Centilion, 2. (1755). How Endrgrenewrshig Theary Creaied

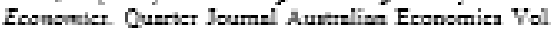
$16 \mathrm{Na} .41-42$.

Ciavrella, M. A., Buchaliz, A. K. Risodan, C. M, Getewsad, R. D., \& Stokes, Q. 3. (1004). The Big Five and venture naceene In there a linkega? Jaumal of Buinsu Venariag, 19, 465-43:

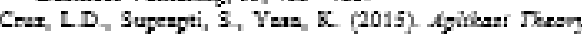

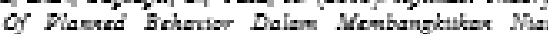

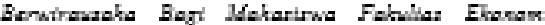
Uryas, Dut Timer Lezic. E-Jumal Eksnomi dan Bimí Univerita Udayaes Val. 4 Ne. 12, pD. 805-920.

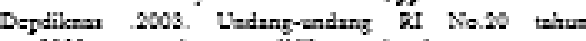
1003 tenteng xistem pendiEkan matienal.

Degen, E 1015. The Effret Of Entregneerambery Edeation

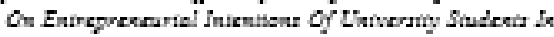
Junkey. Elsensuetri ve Lntatirtik Seyn, 23: 79.93

Deor:E. (1010). Eningoneteurial Deicetioes of Buztecrs

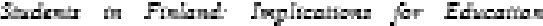
Adveneer in Mensgement, Val.3.7.

EE Riodi. (2014) Metsds Setiutika Jenmetik a Nouparametik. Cetakan Kedea. Tengereng: Patek= Menditi.

Ferreita, J., Mario, L, Razans, Redriguen, R.O. Dinia, A

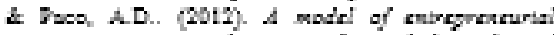
fection : an appitestion of pryehalagieal and bekatienal agproakez. ISBED $19(3)$

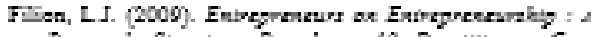

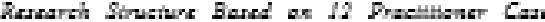
Studiez. Jeumal of Burien Cas Studiea Val.5 Vo.S

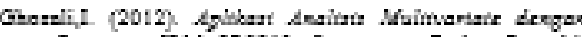
Progran ID.M SDSSIQ. Semarng: Badan Dentrbit Univeritar Diganegare.

Geareli, Imam. 2006. Aqukast Analirs Mulmaniate

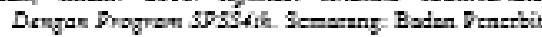
Univeritar Digenegere Gujarati,

Goutich,J. sLoper, M. (2013). Debinzis motharias eurisaty and ieanieg: therry and appleations to edvestional enterponetuerskig. Calumbis.

Gujerati, Demoder N. 1003. Bazie Eesuonetriez. Nev Yock Msorar-bill

Siecher, E.V. Mertis, J.Q. \& Gil, J.G (2011). Nen-

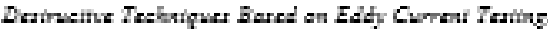
Spain : Journel. Depertment of Signel Thear

Garbuz, G, Aykal, 3. (2006) Entogreneurial teicutioes of yourg ediested poblie in Junky. Joumel of Glahe Stretepie Manapenent, 4(1), 47.56
Hiy, R. R., Kaxh, T. I., \& Carpenter, M. I. (1990). The roile

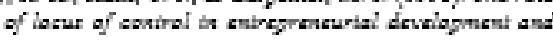
meeers. Joumal of Busizen \& Entropreneurthip, 2(2) $19-22$

Wirzish, R.D, Detern, MD . z shepherd, D. A. (2007) Entrgyneranzky. Me Oraw hill lnternational edition

Wiztith, Debert D., \& Deten, Maichael D.. (2007)

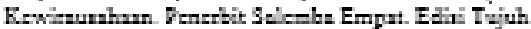

Wenis B. (1004). Entropensuratig Eduentisn: Toured Model of Contingensy Bered Buxiren Dlmaing Asademy of Mensgement Learning and Eduention. $3(3)$. 158.273.

Henis, S.T., Bedell, KE., \& Mumised.M. D. (2007)

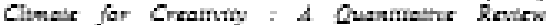
Creativity Revemeh Joume:

Inderti, X. \& Kritiensen, S. (2003). Deiemeinents of Enterpucenarial Ieteritase Val. 5, No.1, 58. 79.95.

lenaieda, E. \& Buelenr, M. (2008). Cempetieg models of entrepreneurial intentiens: the influenes of entrepreasurial velf-effiency and atituden. Dreasntads en Internetienalizing Entroprensurhip Ekstation and Trainiag, IntFrt2008 Cenferenes, 17.20 Julis 1008, Oxford, Otiv, USA. Exte artieule shturo el Beat Daper Awatd, 3rd mak.

Jerz, $M$ \& Marie, M. (1013). Relarien betwee

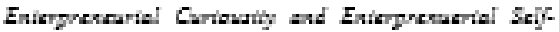

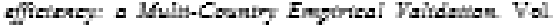
4S. DOt: 10.2478 orga-2013.00027

Kadir, MBA, Salim, M. \& Kamaruein, h. (1011). The Ralstioeshig Benecen Edvestional Suppont and

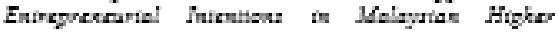
Learning furttwitos Drosedia Social and Behavior Seienta 69 , 2164-2173.

Karskulat A.T. (2016) Deraesilyy Trats or

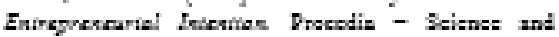
Behavieral Seiene:

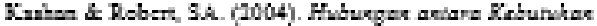

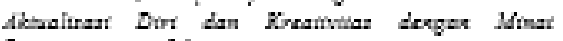
Bontrarwasle Jabarta

Kemala, D. (2017), Defoganh 3kag des . Vowuaz Terhades Miest Benwinasahs. Retrieved fror

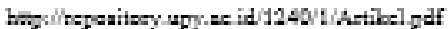

Klusag, M.N. E. Ln, N. H. (2016). The Fectern Affesting Entregreneurial Intentise of the Students of Vietran National Univeraty - A Medietien Analyri of Deresptien teward Entrepreneurahip. Jerras of Eeensmien, Businen and Menusement Val. 4, No. 2

Krueger, X. F. and Cerrud, A. L. (1909) "Entogroneurial

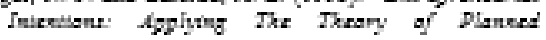

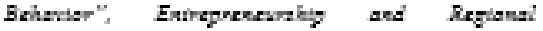
Dewilogment. Dg. 5, 315-930.

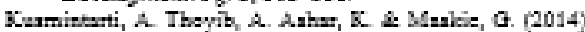

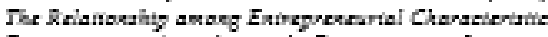

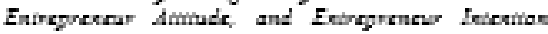
tOSR Jormal of Businen and Management Vel. 1s No.6.

Les-Kelley, L. (2006) Losu Of Contes And Attituden To Werking to Virtul Team. Internetional Joumal of Drojert Managenent, 24(3), 234-243.

Leosg, F.T. \& Feng, 3. Cviture Spezifie Peraensîn Comeialer of Alezieny Amang Chinese and Cavesuier Coürge Sidentr. Axien Journal and Sosinl Drycholagy vol .11 (2)

Linas, F. S Chen, Y.W. (2005). Terturg The

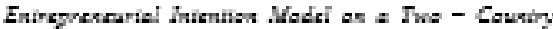
Sangic. Vol.6.

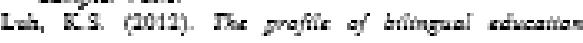
Creativity Revemeh Journel, 16(4), 361-38: 
Malhoten, Narew $\mathrm{B}$; and Bitka, David E. (2007). Markeing Rezcarek: An Asplisd Orientation. New Jeriegr: Drenties-Rall, Ine

Maria, D. \& Tatic (1014). Deningikatae Jiva

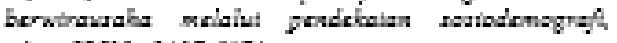
sikas. 1998: : $2407-6171$.

Meillet, 7. (2005). Loeur of eaninal and itz reianos to

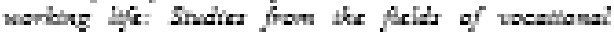
rebabilitation and arail firme is Swcker. Dostoral Theain, Lelei University of Techalogy Sweden.

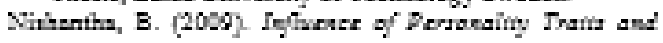
Socto-demegraplite Backgronad of tiedergraduate

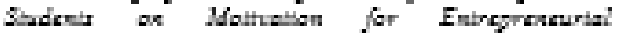
Carev Val.49, No: 2, 71.32 .

Nivientha, B. (2000) Iefherex of Peroesiny Traita and Socto-demograpkice Backprowad of tiedergnaduate

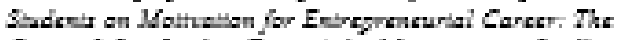
Case of Sn Lanke. Euro Avia Mensgement Studier Ansciatisn (ENMSA).

Nugrahe, S,A. (2007). The Eesusmis Dewibgreed and The

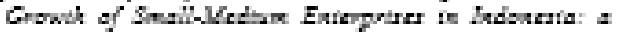
Homeiowe Laverated Trurt Fud Agroak. Tokys.

Nurahma A(1990). tju Validiaz dan Rotiabiliter Sustraree Pergunguies Data. Inkarta.

Oetomo, S.D.S.Santsas,3. (2016) Pougaruk Kenakientrik

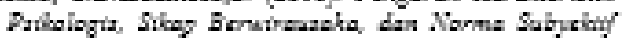
ierbadag eilat berwbauraba. Vol. 20, Xa.3

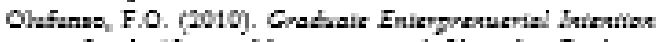
is South Afries: Metwatioes and Obziaclez Businen Menegement, Vel. 5 Sia. 8

Determan, XE. and Kennedy, I. (2000) Enterprias

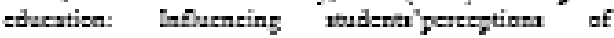
entreprensurahip. Enterpreneurahip Thescy and 7rasties, $23,1,129-144$

Dopeseu, C.C., Beaten,I., S. Robu, B.1. at al. (2016). he

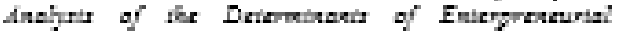

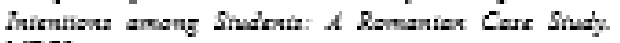
MDD1.

Reie, T.G. \& Warwell, A. (1000). Firid Ieveritganose of the

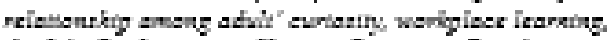
a Job Poglomerec. Duman Ressures Development Quartely $1 \mathrm{i}(1): 5-30$.

Remeikiens,D., Startiene, O., \& Sturdaiens, \&. (20:4). The

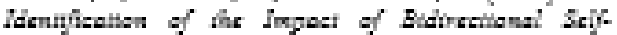
empiopment faciorz on SelcEngiopmeat Sarri-ay and Duratior: Lahian Care Trocedia - Selence and Behaviaral Seienes.

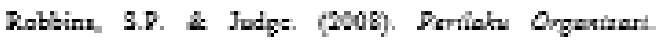
Jakarta, Selemba.

Rabiansea 7.B., Stimgasa, D.V., Dusener, J.C. \& Ru=t, th. B. (1901). An Amitude Apsoack to the Dreatietion of

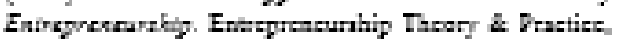
(Oalins $\lambda, 15(4)=13-31$.

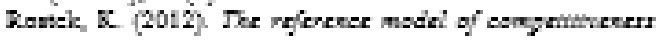

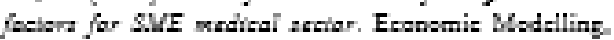
10152. 2009-2048. doi:10.1016/ econmad 2012.00.002

Ratter. J. (1950) Laional Verrus Exierval Covtrol of

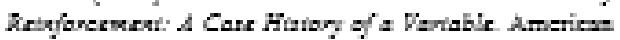

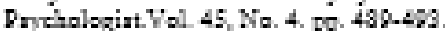

Sehumgeter I. (1934). The Theory of Eeonomie

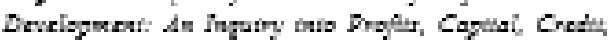
hiercat and the Barnezr Cuele. Harvard Ut.

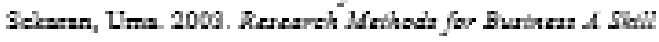
Butiding Approack New York Jaha Wiley A Sen, Ine.

Selvarajuh, C. Kent, $O Y_{\mathrm{w}}$ \& Meyze, D. (20:1). Jecitearioe Joward Entropeecurabjy Uinturrity Studeeds: de Ergerieal Snuly of Malayzier toriveraty Badenir.
Internetienal journal of burien and Social Seienes Vol2 2 No.4

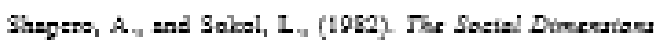

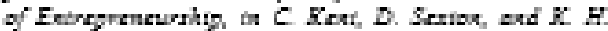

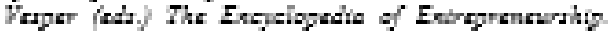
Engleorod Cliff, NJ: Drenties-Hell. 72-60.

Shirakeva, Q. Begutyreva, $\mathrm{K}$. Belizeva, I., Duffer, S (2016). Enirgrencurial onietianse and firse

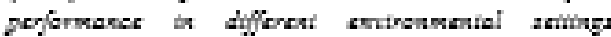

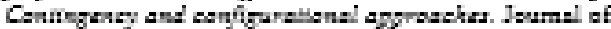
Small Buincas and Enterprias Develogment, 23(3); 703 -727 .

Seruter, David, D. Bets, Kristi \& Reim. (201\%). The

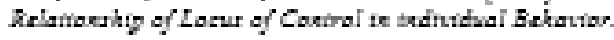
Jeumal of Rehabitutien, Vol. 65, p. 20-16.

Sugijane. (2014) Metsde Denelitien Rembinas (mixed method). Bendang: ALFABET.

Suter,C. (2001) Explantrg Tracher's Quezisena and Foctbeck. Modul = Ons Assenament Taxk.

Suhart, I. \& Sirins, [D. $(2002)$. Fakianglabler yang Bopengaruk Terkaday Niat Xewtranakaes

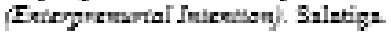

Suhartini, Y. (1011) Anataiz FabiamFakior yang Merpenganuki Minat Makaztrwa dalam Berwirarwazia. Alenenika UDY Valume $7,44.45$.

Suter, C. (2001). Explarteg Teacber's Querturn and

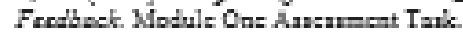

Taramisi S.A. $(200 \%)$ da Examinatios or The

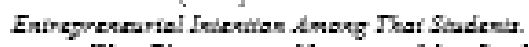

Thamas iN Zimmerer, Noeman M Searborough (2008).Newinasukean der Manajonen Liaka Keelt Salemba eryet.

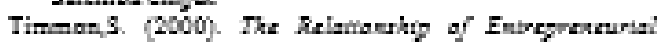

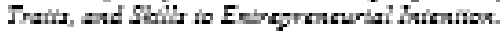

Tony Wijaya. (2007). Hubangas Aduerziry Aniciligenee

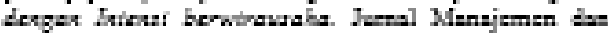
Kewienurahasn 9, 2, 1t7-117.

LAESCO. (2005). Cender Sestive Edusation Siathüter

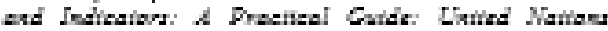

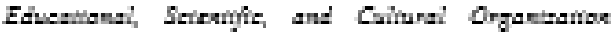
(2NEsco).

UXESCO (2006) Stien-legional Seretrar an Dremaing Enirgoneanarkily Edweatios in Seeondary Sekool Thailend: LNESCO

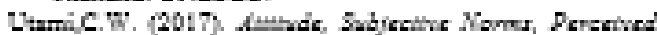

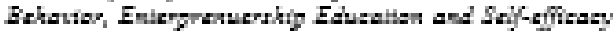

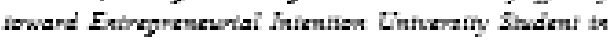

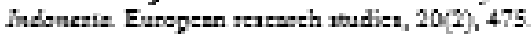

Walghe,W. S Xaim, X. (1016). Faetar that teflueneing

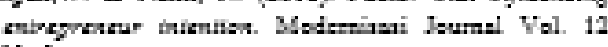
No. 3 .

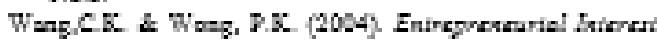

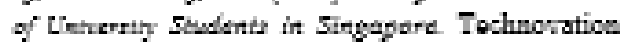
24 (2) $163^{\circ}-172$.

Woi Ni, L, PingL B., Yieg L.L.,Sem,N.H. \& Lih,J.W. (2012), Ettepprenterial Intidtide: A Study.

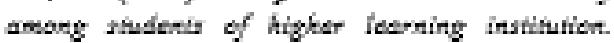
Vol.23, 1-7.

Wentbrook dan Reilly. (2013). Bnatd Managemdnt and Straiter: Penertit Andi.

Wibono, A. (2013). Martajimien Pdrtidibart Kardkter. Yogyzicarta: Pustaka Polajar

Wulandari, Annz, 2009. Pengaruh Lingkungu Elestoral dan Lingkungu Intemal Teshadap Orisutasi Wiranaka Dalam Upaya Meningkatkam Kinerja Univensitas Sumatara Utara 79 
